\title{
Henry James's Sense of the American Civil War in The American Scene
}

\section{Introduction}

When you haven't what you like you must perforce like, and above all misrepresent, what you have. (James 1968: 456-7) ${ }^{1}$

Henry James is well known for his overall interest in how the mind works, how consciousness comes into being through the process of understanding. He has worked out a model of how consciousness operates in his fictional productions, elements of which can be found in his literary essays, too. According to the Jamesian model of consciousness, facts exist in the form of impressions in the individual, and then impressions are transformed into the experience or the sense of the thing perceived. (Cress 2002: 61-2) Experience, in turn, is never limited or complete, it is an ongoing process which constitutes one's consciousness.

Apart from his literary output, James also produced several volumes of nonfiction where the model of understanding is present. My question in this essay centers around the problem of how we can find the Jamesian interest in the workings of the mind in his book The American Scene he wrote about his travels in the US after a 25 year absence. My reason for asking this is that his The American Scene is often considered today by Jamesians from the perspective of race, class, politics, public space i.e. from perspectives

\footnotetext{
${ }^{1}$ Henry James. The American Scene. Ed., Intr., Leon Edel (London: Rupert Hart Davis, 1968). Henceforward page numbers in parenthesis refer to this edition.
} 
“James's Sense of American Civil War in The American Scene" James's Wars. Miroslawa Buchholtz et al., eds. Frankfurt: Peter Lang, 2014. 75-90.

after the cultural turn and the spatial turn. (Follini and Horne 2008: 1) Yet the text itself also relies heavily on James's formally oriented rhetoric of understanding, an indication that it would provide ideal opportunity for integrating a contextually oriented critical agenda with an investigation of James's formally oriented critical rhetoric. My idea is that his model of understanding is at work in his descriptions of his travel impressions, and thus his model of understanding is being used to criticize contemporary US life in general at given specific contexts he calls scenes.

With his travels in the US, besides criticizing the present he also sets out to experience and formulate his sense of the American past. In the final part of the book his sense of a Southern past is also formulated, during his excursion to the South. I claim that James's experience-oriented reading of the US South spells out a criticism of the sense of "The Old South" that for James exists as a mere ghost of itself only. However, while formulating extremely critical statements about his sense of the US South and Old South, he repeatedly confronts anxieties concerning the relevance of his own cherished interpretive method to the material offered. My hypothesis is that James's whole analytical enterprise based on the model of understanding becomes questioned in the US context, i. e. on the final pages of The American Scene dedicated to an account of the US South.

This essay investigates the Southern segment of The American Scene from the perspective of the model of understanding and the sense of the South James constructs there in order to analyze the reasons why the Jamesian interpretive model seems to fall apart there. The paper is divided into three parts. The first part explores James's motivation to travel and how he defines his task in terms of experience to be gained. The second part looks into how the model actually works in his reworkings of impressions about the South. The third section focuses on difficulties James encounters whilst making sense of the American scene with the help of his model.

\section{The Student of Manners: The Analyst as Protagonist}

James starts out on his tour of the US with great expectations, he aims at collecting material for a new book. Primarily, he is interested in the human aspect of the changes 
"James's Sense of American Civil War in The American Scene" James's Wars. Miroslawa Buchholtz et al., eds. Frankfurt: Peter Lang, 2014. 75-90.

that had happened in the US since his last visit in 1883. His American journey starts at the end of August, 1904 with visiting relatives and friends in the Northeast. Boston and NYC are the most important locations for him because of the striking difference between the image of them he has from his childhood and the present picture they project in 1904-5. His accounts, therefore, are infused by criticism and nostalgia. In the winter he travels South, starting with his visit of Philadelphia and Baltimore in January and concluding with his stay in Florida in late February, 1905. Afterwards he returns North, first to Philadelphia, then NYC, finally Cambridge. The third section of his trip is centered around giving lectures. First, he goes South and West (St. Louis, Winnetka, Chicago, Los Angeles, San Diego, San Francisco, Portland, Seattle) and then returns to the east (Washington, Boston, New York, Atlantic City) giving lectures as he proceeds. Eventually, having revisited a circle of friends, he sails for England in July, 1905. (Edel 1968: 467-8) The American Scene relates his adventures till the end of the Southern trip. In this essay, I am concerned with the Southern leg of his journey that is discussed in the final chapters (9-14) of The American Scene and provides a most critical view of the South in particular and of the US in general from "the human side." (436) I am concerned with what 'the human side' of the historical changes means for the narrator protagonist of The American Scene.

James the hero and narrator of The American Scene enacts a self-reflective performance and throughout the narrative he is at work defining and re-defining his task. The narrator refers to himself and his task when he consistently calls himself a restless analyst who is a student of manners. The analyst has a supreme sensibility (309) which is aimed at deciphering social scenes. His main problem with US social scenes is that they seem to work towards simplification, as in general social discrimination seems negligible in the US. (305) In other words, James's task of social analysis is aimed against the trend not to analyze he perceives in the US. He turns this situation around by claiming that his task in traveling is to use his faculty to analyze, "a circus ring for the exercise of one's faculties, for one's conscience." (310) James, while at task, claims that there is "for the restless analyst, no such thing as an unrelated fact, no such thing as a break in the chain of relations," (312) and his aim is to place scenes into chains of relations. James illustrates his sense of his position by describing himself as a visitor to a new place who is waiting, somewhat longer than he thought, for admission in the drawing room. He is at 
“James's Sense of American Civil War in The American Scene" James's Wars. Miroslawa Buchholtz et al., eds. Frankfurt: Peter Lang, 2014. 75-90.

leisure to collect impressions about the host he is to get to know through the space and decorations in the room. (315)

For James the primary role of the analyst's deciphering activity is to make things “interesting." In Jamesian parlance creating an interest in things equals to making things communicable. (312) In TAS the most lively source of interest is the question of America, where, according to James, the American scene brings up material and handles it as part of a social experiment the outcome of which is incalculable. (357) So it is the likely outcome of that experiment that concerns James and this outcome should be imagined and made communicable. Yet, to James, in America there is, in general, little to say, as the American scene is just the opposite of the European excess of relations, where there is too much to comment. (357) With a surprising twist, however, James locates a task in the lack of possible commentary. Instead of accepting a lack of interest in things, he sets out to generate interest in them. As James puts this, "association reigns here" (360), in other words there is a quantity to be read into the American Scene to make it interesting. James even uses an analogy to explain what he means by associated interest in the American scene when he compares it to an actual scene, California. California before and after rain resembles the American scene before and after an associated downpour of interest in it, bare and luxuriant, respectively. The basic task of the restless analyst is to add interest to the seemingly bare American scene.

The restless analyst has a specific methodology, he brings interest into his readings of the American scene by associating an interior social aspect to the exterior fact. First, this is indicated by the synonyms of the term 'analyst' James uses when he refers to himself. Repeatedly, he also calls himself 'student of manners' and 'student of social life.' Also, when he seeks to explain he tries to find the net of relation a single "fact" may belong to, and the revelation of the relationality is called the social aspect. The associated social side of events emerges as part of the analyst's work with them.

The analyst's task to associate can be translated into terms of a general model of understanding. The analyst proceeds with his associative task by transforming facts into impressions. The little hard facts, as James puts this, only gain their communicated importance when they become great soft facts as impressions. Impressions, however, are not easy to formulate: one needs to know how to look and see (366), and also how to separate and distinguish in order to generate them. (368) These impressions, in turn, 
"James's Sense of American Civil War in The American Scene" James's Wars. Miroslawa Buchholtz et al., eds. Frankfurt: Peter Lang, 2014. 75-90.

form the basis of experience, which is the after-taste of impressions. For James, then, experience is read into phenomena through a processing of impressions. Also, experience and its process comes to the fore when one travels, "one needs to renew his appreciation of the mystery of experience" (395) then. James inserts a passage celebrating the mystery of experience in the American context at the beginning of his section on Charleston, meditating on the relative lack of interest generated in him during the journey up to then. This impression itself makes him think of the mechanics of experience in America: "The large negatives, in America, have, as well as other matters, their meaning and their truth: so what if my charged consciousness of the long way from Richmond were that of a negative modified by small discomforts?" (396) It is the meaning of the lack of interest that continues to concern James in the American context.

His account of his stay at Biltmore house near Asheville, North-Carolina testifies to his experience of the lack of interest. Biltmore was the estate of George Vanderbilt, constructed at enormous cost and attention to detail. James was invited as a guest of the Vanderbilts and he disliked the largest private house of the country enormously. Writing to Edith Wharton in 1905, he describes the house as vast, impenetrable, only few guests wandering in its vast cold space. (Luria 1997: 298-9) In The American Scene, James mentions Biltmore via allusion, as a modern miracle in the mountains of North Carolina, a splendid and vast demonstration of wealth, a "colossal French château" (Edel 1968: 478) 2500 feet in air. Somebody had managed to demonstrate large wealth and to indicate he cares for a fine cluster of ideas (396) - but for James this only enhances the fact that all this splendor exists in parenthesis, is an accident in the empty element of the beautiful North Carolina countryside. The demonstration is dreary (397) for James because if its lack of relations, because of its isolation, because nobody cares for it there. From the perspective of his task to construct an experience of America, the Biltmore house seems exemplary. It was built with the intention to arouse interest, impressions, social experience, but in practice the spatial and social isolation of the place serves to illustrate the emptiness of its element and makes the whole enterprise loathsome.

\section{A Southern Impression}


Faithful, experimentally, to desperate practice, I yet had to renounce here - in the main residential street - the subtle effort to "read" a sense into the senseless appearances about me. (392)

\section{Particular application}

What scenes of the US South James would be interested in - the term 'interest' in comport with his focus on human understanding and relations? As the analyst of social scenes, he is interested in the human side of history and of the present. In the South, he cherishes a specific expectation for his excursion, he hopes to find out about the "social consequences of the prime democratic idea," (324) the "democratic assimilation of greater dignities and majesties." (360) Also, he is interested in the intense and tragic drama of the Civil War and how its spirit is kept alive in the South. (369)

James's major concern throughout his journey is that he fails to find an interest in Southern facts. What he finds instead is a void without either life or memories wherever he looks. One can trace his itinerary and pinpoint the exact reason for his disappointment in each location he comments on. Baltimore, at the beginning of his journey, is declared a dead city dominated by the ghostly presence of the war (310), with everybody out of town, resulting in a simple sweetness that does not trigger the imagination of vice in the analyst at all. Washington, the city of conversation, and therefore of high social potential, only talks about herself. (343) Conversation in Washington does not match its outward view, i.e. the wonderful and rich palaces, monuments, plans and gardens intended to impress the voter. $(353,356)$ Richmond, the old Confederate capitol turns out a tragic ghost haunted city that shows no consciousness of anything (369-70) that is so passive it even challenges the analyst's perceptive resources. The social scene in Charleston is sordid, lost in the scale of space and mainly speaks of the number of things not cared for. (397) Eventually, Florida and its hotels house people who are not in their place, they are unrelated and "would only fall into their place were the social proposition completed.” (428)

From the perspective of his interest in the possibilities the new Democratic age has for the South, he has nothing to show. He admits squarely that he cannot tell what the Southern future will be like. (392) Although he tries to work out new alignments by 
"James's Sense of American Civil War in The American Scene" James's Wars. Miroslawa Buchholtz et al., eds. Frankfurt: Peter Lang, 2014. 75-90.

desperate practice, in fact he has no material to use. As yet, there is no such thing as the new South, no new social order (382) to account for, although after the collapse of the (antebellum) old age, a social revolution (386) is supposed to have taken place. Yet James can only locate gaps, the lack of a new order and also a lack of the sense of the past.

As he travels, he is intent on collecting traces of the glorious past in Washington and in the ex-capital in the form of monuments, museums, buildings, persons but he only manages to see vulgar traces of a past not cared for at all. His account of his visit to the Museum of the Confederacy in Richmond and Lee's Monument next to it are telling examples of this impression about the lack of the sense of the past in the South. James is out to find legend of the South, make it accessible but only meets trivial elements of history. (383) He visits the Museum to find the spirit of the Southern legend descended "by reason of the very nudity and crudity, the historic, the pathetic poverty of the exhibition." (384) The exhibits "spoke only of the absence of means and taste" and therefore again offered a chance for association, the "old trick" the hero employs again. He sees the little old lady in charge of the exhibit as the only interesting element of the exhibition, she only provides the contact with the past: He felt himself up to his neck in a delightful, soothing, tepid medium, the social tone of the
South that had been. It was but the matter of a step over - he was afloat on other waters, and
had remounted the stream of Time. I said just now that nothing in the Museum had beauty; but
the little old lady had it, with her thoroughly "sectional" good manners, and the punctuality and
felicity, that inimitability, one must again say, of the South in her, in the patriotic unction of her
reference to the sorry objects about. (384-5)

All in all, it appears interesting for James how the ugly and sorry objects ventilate a theory of eternal rancour, how "a flame colored idea has flowered out of the fact" and began to play its part as valuable, enriching, romantic legend for the new generation after the war. (386) The Jamesian interest in this is "psychological," and from the psychological perspective the need for legend indicates a moral and social gap. James's interest focuses on the process of how the story of the four tragic years has been turned "epic" in answer to the needs of the starved Southern spirit. "It was impossible, from room to room, to imagine a community, of equal size, more disinherited of art or of letters. Those about one were the only echoes." (386) The melancholy void one finds in 
"James's Sense of American Civil War in The American Scene" James's Wars. Miroslawa Buchholtz et al., eds. Frankfurt: Peter Lang, 2014. 75-90.

the rooms can only be catered for psychologically by nursing the idea of a rich heroic fact that hides the ugly facts.

Lee's monument in Richmond conveys a similar experience of social and moral want for the narrator. The monument is an equestrian statue of the general made in Paris after the latest fashion. It is located at the meeting point of three or four crossways, but there is no proper square formed around it as there are only groups of ugly new houses indicating a semi-circle. The space is both empty and ugly, James states. (393) For James, the exquisite artistic value and the actual desolate position of the statue carry an impression of something valuable lost. It is just right that the statue sits so high up above the ground, so that it can overlook its surroundings, ignore the traces of futility all around. (394) The statue's perched and ignoring position symbolizes the historic poverty of Richmond - there are scant traces of the past only because the past to be remembered is scant also: "it is the poverty that is, exactly, historic: once take it for that and it takes on vividness." (394) There is a wider significance to the scant past turned into a legend in the South, but what that significance may be is something James is only beginning to recognize.

Part of James's failure to understand the Southern legend is connected to his overwhelmingly negative image of the local African-American population ${ }^{2}$ he calls 'darkies.' Repeatedly, he tells about his impression of the "tatterdermalion" darkie (375) loitering at the station, doing nothing, standing for a type that carries the doom of the South. (ibid) In the same vein, in Florida, the black waiters are proclaimed useless because they have an ineptitude for alertness, although James would have thought their deficiency corrected as time passed. (423) Furthermore, an important reason why so many things are not cared for in the South is explained for him by the fact that in many places negroes are more numerous than the whites, and 'darkies' can not care, not even the few whites, he says, can care in such a context. (398) The case is that "Southerners are imprisoned by the legacy of the presence of the negro" today (Blair 1995: 3) the same way as they used to be. (375) As James looks out of the window of his Pullman car, he observes "(i)t was a monstrous thing, to sit there in a cushioned and kitchened Pullman and deny to so many groups of one's fellow creatures a claim to a 'personality';

\footnotetext{
${ }^{2}$ Leon Edel argues that "Negroes scarcely figure in this book" yet James perceives the central issue of their emancipation. See: Leon Edel, "Introduction" (op. cit.), xxii. To my mind, James perceives the difficulties of emancipation mainly.
} 
"James's Sense of American Civil War in The American Scene" James's Wars. Miroslawa Buchholtz et al., eds. Frankfurt: Peter Lang, 2014. 75-90.

but this was in truth what one was perpetually doing." (398) In other words, there is indeed a basically negative discriminating attitude James adopts towards the local colored population in general, an attitude he is aware of but does not contain. Moreover, one needs to add that he extends this attitude to Southern whites, too, who are depressed, desolate, and care not about "personality" either. Southerners' (white and black) lack of concern represents the social and moral void James is in the process of unveiling and making sense of.

As he keeps looking on, James locates a fallacy as the underlying principle of the general Southern lack of distinction. It is the Southern idea of a separate state based on the work of slaves that is severely questioned in the light of Jamesian experience. It was "a cause which could never have been gained" he says (394), as Lee's lonely monument symbolizes. He elaborates this idea in connection with his Southern impression in Richmond. At a senseless street corner he enjoys a moment of understanding his feeling of intellectual bankruptcy as the lack of reference, but a "sad, large poorness" (371) that has its reason in the past, in the absurdity of the idea that forms the basis of its identity. Let me quote the whole passage because I find it central to the Jamesian understanding of the US South:

I was tasting, mystically, of the very essence of the old Southern idea - the hugest fallacy, as it
hovered there to one's backward, one's ranging vision, for which hundreds of thousands of men
had ever laid down their lives. I was tasting of the very bitterness of the immense, grotesque,
defeated project- - the project, extravagant, fantastic, and to-day pathetic in its folly, of a vast
Slave State (as the old term ran) artfully, savingly isolated in the world that was to contain it
and trade with it. This was what everything round me meant--that that absurdity had once
flourished there; and nothing, immediately, could have been more interesting than the lesson
that such may remain, for long years, the tell-tale face of things where such absurdities have
flourished. (371)

For James his experience of understanding gives a warning, a need for establishing a new set of values instead of the Slave-scheme in the South before social life could begin to change. 
“James's Sense of American Civil War in The American Scene" James's Wars. Miroslawa Buchholtz et al., eds. Frankfurt: Peter Lang, 2014. 75-90.

James's criticism of the idea of the Old South forms part of his criticism of the American Scene in general. The way he comments on the American family, the American woman and on the American hotel-spirit in the South has a relevance to his general critical view of the US that is being refined here.

Firstly, he dislikes the organization of the American Family as it appears in the South and the US. His impression from the Charleston country club forms the basis of the comment. The social relations in the country club show the principle of the US family at work. In the US the young family is a basic unit of society, it works in the horizontal sense, a lateral dimension that expresses itself by number rather than by name. The family extends through social space democratically, this sense of the family is "an eminent field of democratic demonstration." (325) As opposed to this, the European family works in the vertical sense, its time aspect and the questions of ascent and descent are of importance (324), it is designed aristocratically. In the US country club the whole social extension of the family is accepted, so no discrimination is made of young and old, male and female, husband and wife, providing a scene of "universal eligibility" (325) James dislikes heartily. He would prefer the European principle of perpendicular differentiations. This whole issue gains interest for James in its relation to the question of manners. In Europe, there are social differentiations and precautions that seem diverting for the American mind, but for James it is dreadful to think that without the artistocratic discriminations represented in the form of manners social differences would cease to exist. James sees the intensity and the continuity of the association in the US, and is certain that "experience" and "real taste" (327) could add countless advantages to this scene.

The question of American women haunts James all through his American journey in the form of comments but he finds the vulgar young American girl in Florida as a possible threat for the future. Women in general are of interest to him as "the woman is two-thirds of the apparent life -- which means that she is absolutely all of the social" (346), exactly the sphere he would be interested in. Yet the appearances American women construct are far from being satisfactory for him. The young American girls he watches from his window are bareheaded, assertive, loud, open, and above all reveal their intimate relations to men in public in a way that is shocking. (456) He puts this problem down to the problem of type: as with men, there are relatively few types in the 
"James's Sense of American Civil War in The American Scene" James's Wars. Miroslawa Buchholtz et al., eds. Frankfurt: Peter Lang, 2014. 75-90.

US. In US hotels you find men to be of the business block, all successful, decent, sociable and have good humour. Their wives are also of one type, indulged ladies of such lords. They used to be the vulgar young girls who do not engage the imagination of the spectator. The neutral respectability of these types bothers James to the point of asking a rhetorical question: to what extent the type has invented the young girls in question is answered by the former description already.

James's criticism of the South and the American Scene culminates in his description of Southern hotels and of the general American hotel-spirit they embody. He stays at hotels in Richmond and Charleston and finds the institution similar everywhere: it is great, shiny, and empty, as if they were signposts from the North scattered about the South. In Florida the hotel life takes on a sudden intensity, as hotels dominate the holiday resorts, and in the clean Florida air their effect is quite spectacular. James compares this impression to the one he had had of the Waldorf-Astoria in New York City not long before. The effect consists in the impression of the "perfect, the exquisite adjustability of the "national" life to the sublime hotel-spirit." (439) Analyzing the relation of national life and the hotel spirit, James is content to make the hotel-spirit the stronger in the sense that it is full-blown and expert, and thus the national life can rely on it to help out its own undeveloped and passive social organization. The problem with the hotel-sprit for James is not only that it is unifying but also that while it pretends to meet the need of American ideals, it in fact creates new American ideals. It is not only educative but is also prescriptive, the great national ignorance is taken advantage of artfully by the hotel-spirit that defines relations. This is the revelation James encounters instead of a fulfilling meal at his Florida hotel He finds this revelation troubling from the perspective of "the individual" or "the informed few" looking at "the crowd" or the "uninformed" (441) masses:

I seemed to see again ... the whole housed populace move as in mild and consenting suspicion of its captured and governed state, its having to consent to inordinate fusion as the price of what it seemed pleased to regard as inordinate luxury. Beguiled and caged, positively thankful, in its vast vacancy, for the sense and the definite horizon of a cage, were there yet not moments, in which it still dimly made out that its condition was the result of a compromise into the detail of which there might some day be an alarm in entering? (441)

It is James's notion of individuality existing in differentiations, taste, manners that is captured by the hotel-spirit in America. The cumulative sum, the golden-mean as the 
universal ideal oppresses him as the quality that has no need for his kind of individual sensibility.

James makes out the Pullman car as the final symbol of the American spirit he would like to resist at the end of his travelogue. The car provides a vantage-point for his descriptions and observations, the car window as the aperture that gives the shape of his American impressions. ${ }^{3}$ Yet, at the end of his journey he defies the vantage-point the Pullman provides. He describes the car as "the missionary Pullman" (465) that invites the spectator to admire its achievements even when there is nothing worthy of mentioning outside save traces of the erasure of native cultures. At this point the narrator would like to stage a break with its prefigured perspective and question the celebrated achievements of "the symbolic agent," the Pullman.

\title{
3. Desperate Practice: Lessons Learnt and Re-learnt
}

\begin{abstract}
Of how grimly, meanwhile, under the annual rigour, the world, for the most part, waits to be less ugly again, less despoiled of interest, less abandoned to monotony, less forsaken of the presence that forms its only resource, of the one friend to whom it owns all it ever gets, of the pitying season that will save it from its great insignificance - of so much as this, no doubt, I sufficiently renewed my vision. (462)
\end{abstract}

Although James sets out with a very definite task for himself as the student of manners, the analyst of the American scene and of the sense of the South, eventually he ends up questioning his own critical enterprise. The overall lack of material to process indicates that his whole methodology of experience is without use in the American scene.

\footnotetext{
${ }^{3}$ James's descriptions of metropolitan machineries of the Modern city that indicate his distance from the Modern spirit is analyzed in Wendy Graham's "Notes." Graham points out the critical potential of the architectural dscriptions of NYC and Chicago - an observation that I think is valid in the smaller-scale Southern context, too. See esp. Wendy Graham "Notes on a Native Son: Henry James's New York" (American Literary History 21(2009): 2), 247-8.
} 
"James's Sense of American Civil War in The American Scene" James's Wars. Miroslawa Buchholtz et al., eds. Frankfurt: Peter Lang, 2014. 75-90.

Self-questioning forms part of James's habits as a way to reflection, but now there is a new, desperate tinge to it that appears. Already at the very beginning of the section on the South he begins to ask himself the question if he is reading too much into things. (330) Let us remember that by this point he had also registered that in the face of the overall lack of reference and material the analyst needs to exercise his associative potential to the full and thereby make sense of the lack of sense. The question of reading too much into something, then, refers to the overall critical enterprise James had undertaken to carry out. It is the "old habit of supposition" (330) that makes him go on, although he is chilled by the feeling that "his feelers drop" that his "questions [are] arrested" (ibid.) whilst he is trying to entangle the mystery of Southern manners. At stake is survival, he points out later as James the narrator relates the opinion of James the protagonist: "if one has not at last learned to separate with due sharpness, pen in hand, the essential from the accessory, one has only, at best, to muffle one's head for shame and await deserved extinction." (368) So the project of making sense out of senselessness (from the accessory) is vital, is a legitimating activity on the part of the analyst. If it cannot be performed, the whole analytical enterprise and also its agent go bankrupt.

The threat of extinction is not the only motivating factor for the analyst to go on with reading. In Richmond he realizes that his expectation to find a Southern character was utterly false and reveals the understanding that it is the lack of reference that has to be reestablished in its historic connections. Just before experiencing this understanding of the South, the analyst is lost seeing only the lack of any historical consciousness, and is baffled by the void he finds. His reaction is emotional "[o]ne could never consent merely to taking it for that: intolerable the discredit so cast on one's perceptive resources." (370) So it is not only that he faces extinction if he cannot pursue his task but also a sense of personal failure, shame, that makes him want to see "by desperate practice" (392) and read sense into senseless appearances even if nobody cares for the "communicated importance" (337) of the void.

Another self-reflection of his concerns the validity of his associations. There is a possibility that his impressions are wrong. How can it be that it is only him who has such a critical view of the hotel-spirit? Can his associations produce the wrong reading of the scene: "How, when people were like that, did any one trust anyone enough to survive? 
“James's Sense of American Civil War in The American Scene" James's Wars. Miroslawa Buchholtz et al., eds. Frankfurt: Peter Lang, 2014. 75-90.

Wasn't it, however, at last, non the less, the sign of a fallacy somewhere in my impression that the peace was kept, precisely, while I so luxuriously wondered? - the consciousness of which presently led me round to something that was at the least a temporary, a working answer." (426) He cannot be sure, but he supposes he is on the right track and drifts on.

While drifting along, the analyst becomes aware of the fact that there will be no conclusion to reach with his travels. He set out to study the question of manners in the largest sense in the US (317), to see the "social consequences of the straight application of the prime democratic idea." (324) What are Southern manners like forty years after the process of democratization started? Is there such a thing as a democratic Southern character - these are the questions that are arrested by the experience of void: lack of character types, a lack of historical consciousness. Instead, he now lets things drift, and he focuses his attention on making the surface mean something. That is why he marvels at the mystery of experience again. (395) He only finds the ghost of the old Southern tradition, not the Southern tradition, and wonders if his sensibilities have been wasted here. He has identified a predominant social type he finds base and vulgar, a type he has encountered elsewhere in the world but now should make a central figure of his explorations. The question is not of the type but of its value: "why did it now usurp a value out of proportion to other values?" (425) Why is it that the analyst cannot pursue his task of making distinctions and finding out about manners due to the dominant vulgar type that excludes differentiations? The type is base because it is unformed, undeveloped, unrelated. (428) In terms of the analyst's task, the social result of the democratic experiment in the South, there is no conclusion to make because it would be a devastating conclusion.

Instead of drawing conclusions, the analyst goes on associating by "sordid habit" as he knows no better. (425) His final associations bear relevance both to his experience of the South and to his task to produce experience. On the one hand, he associates the analogy of the Nile to his impression of Southern swamps and to his impression of the South. The scene, for him, is like the Nile before the culture of the Pharaohs, because Florida swamps are like the Nile flood region waiting for the annual water supply to come that would make it fertile - without the culture but with the potential to provide for such a culture. The scene is also similar to California because there the impression is that 
"James's Sense of American Civil War in The American Scene" James's Wars. Miroslawa Buchholtz et al., eds. Frankfurt: Peter Lang, 2014. 75-90.

of "an unconscious and inexperienced Italy" (462) On the other hand, his image of the long awaited flood that renews the ugly world and "shall save it from its huge insignificance" (462) has a relevance to the process of making sense through impressions and experience. The way the analyst makes sense of barrenness in the South and in the US again and again is similar to the way the Nile saves the land from becoming a desert every year. Association makes a void of material have an importance, beautiful, varied, and thereby saves it from insignificance. It is a miracle to happen again and again however futile the repetition may seem - "[o]f so much as this, no doubt, I sufficiently renewed my vision" (462) James comments. Association must go on as it is the only source of value in a world without the values of importance, beauty, and difference.

\section{Conclusion}

James the restless analyst of manners explores the US South intending to understand Southern character and the sense of the South before the war. He sets out to perform his task equipped with a notion of understanding that is largely associative: impressions will form a vision of the issues he is interested in. Yet, however hard he tries, he fails to find the traces of either Southern character or the sense of the South. Instead of character he finds a base and vulgar social type that predominates social spaces of the South, especially the hotel and its dining room. Instead of the sense of the Southern past he finds the ghost of the South and of Southern tradition, the very idea of the Slave State a grotesque absurdity that cannot generate historical consciousness. He describes the "darkie" as an agent who plays an important role in the lack of character and in the lack of historical consciousness, because his intimate presence prevents the whites from developing these qualities, too. He is aware of the ghastliness of excluding many groups of people from the notion of 'character' able to appreciate discriminations but nevertheless does so even if he finds himself the only 'character' present, an open admittance of a racially biased attitude. Despite warning signals that his whole analytical enterprise focusing on the human side and social relations may be a fallacy, he goes on generating associations that, according to him, can save the world from insignificance. 
"James's Sense of American Civil War in The American Scene" James's Wars. Miroslawa Buchholtz et al., eds. Frankfurt: Peter Lang, 2014. 75-90.

\section{References}

Blair, Sara. 1995. "Documenting America: Racial Theater in The American Scene" The Henry James Review 16.3. 264-272.

Cress, Jill M. 2002. The Figure of Consciousness: William James, Henry James and Edith Wharton. New York: Routledge.

Edel, Leon. 1968. "Introduction" and "Notes" In James, Henry. The American Scene. London: Rupert Hart-Davis. vii-xxiv. 466-482.

Follini, Tamara and Philip Horne. 2008. "Introduction" The Cambridge Quarterly 37.1. $1-2$.

Graham, Wendy. 2009. "Notes on a Native Son: Henry James's New York” American Literary History 21. 2. 239-267.

James, Henry. 1968. The American Scene. Ed. Leon Edel. London: Rupert Hart-Davis.

Luria, Sarah. 1997. "The Architecture of Manners: Henry James, Edith Wharton, and The Mount” American Quarterly 49. 2. 298-327.

Ágnes Zsófia Kovács teaches courses on American literary history and literary theory at the Department of American Studies of the University of Szeged, Hungary. Her research interests include Modernist American literature, contemporary ethnic fictions, detective fiction, theories of the novel, nonfiction genres. She published The Function of the Imagination in the Works of Henry James with Mellen in 2006, and Literature in Context: Essays (JATE Press) in 2010. 